\title{
Quantitative assessment of IgG and IgA subclass producing cells in rectal mucosa during shigellosis
}

\author{
Dilara Islam, Béla Veress, Pradip Kumar Bardhan, Alf A Lindberg, Birger Christensson
}

\begin{abstract}
Aims-To assess quantitatively both the morphological changes in the rectal mucosa and the changes in the relative frequency of IgA and IgG subclass producing cells found in the rectal mucosa during the acute phase of shigellosis and at convalescence.

Methods-Rectal biopsies from 25 Shigella dysenteriae 1 infected patients, 10 Shigella flexneri infected patients, and 40 uninfected controls were studied. Morphological changes in the mucosa were graded. The frequency of IgA and IgG subclass producing cells was assessed. In addition, immunostaining for secretory component in epithelial cells was analysed.
\end{abstract}

Results-Using morphological grading, $20 \%$ of the 35 patients studied had advanced inflammation (grade 3 ) in the acute phase of the disease. At convalescence, grade 1 inflammation was seen in $37 \%$ of the patients and in $10 \%$ of the controls. In the acute phase, as well as at convalescence, the number of $\operatorname{Ig} A_{1}, \operatorname{Ig} A_{2}$, and IgG $_{2}$ positive cells was significantly higher than in the controls. The results were related to the histopathological degree of inflammation.

Conclusions-In shigellosis, there is evidence for a prolonged humoral response residing in the mucosa long after the clinical symptoms have resolved, suggesting that shigellosis induces persisting mucosal humoral immune and inflammatory responses, remaining at least until 30 days after the infection.

(F Clin Pathol 1997;50:513-520)

Keywords: shigellosis; degree of inflammation; immunoglobulin producing cells

Shigellosis is a significant cause of morbidity and mortality in developing countries, such as Bangladesh, particularly in children under the age of 5 years. ${ }^{1}$ Of the four species of Shigella causing diarrhoeal diseases, the most severe disease found in Bangladesh is associated with $S$ dysenteriae 1 and $S$ flexneri.

In most cases, the infection is limited to the intestinal mucosa, and systemic infections are rare, especially in adults. Invasion, multiplication, and the spread of shigella (a complex series of events) ${ }^{2-4}$ causes an inflammatory enteritis. The most pronounced lesions are seen in the rectosigmoid area and the intensity of the inflammation decreases in the proximal direction. ${ }^{56}$ Colitis and ulceration in severe shigellosis result in the loss of the protective mucosal barrier, allowing bacteria and bacterial antigens to enter into the circulation. ${ }^{78}$ The histological features of shigella colitis during its acute phase are indistinguishable from those of other forms of acute infectious colitis. In addition, during shigellosis, excessive epithelial hyperplasia, distortion, and branching of crypts are seen, features that are commonly seen in patients with chronic ulcerative colitis and in Crohn's disease. ${ }^{78}$

The most well defined part of mucosal immunity is the secretory antibody system; it depends on local production and selective epithelial transport of polymeric IgA (pIgA) and pIgM. ${ }^{9}$ Mucosal surface protection afforded by secretory IgA (sIgA) antibodies depends on the local number of IgA producing cells, their subclass distribution ( $\operatorname{IgA}_{1}$ and $\operatorname{IgA} A_{2}$ ), and their ability to express joining $(J)$ chain. Different classes and subclasses of immunoglobulins exhibit distinct functions and the subclass response to an infection may be of biological significance. In various gut diseases, local immunoglobulin production is altered, both with regard to class and subclass.

Disease associated alterations of mucosal IgA subclass production may be of biological importance. Enhanced secretory immunity may accelerate the pathogenesis of the disease. In the large intestine, the number of immunoglobulin containing cells seems to be lower in the rectum than in the sigmoid colon and ascending colon. ${ }^{10}$ IgA producing cells are the most frequent immunoglobulin producing cells in the large intestine. IgG producing cells normally constitute $3-5 \%$ of the immunocytes in the intestinal mucosa. IgG producing cells are more numerous in the appendix than in the colon and accumulate preferentially adjacent to lymphoid follicles, suggesting that $\mathrm{IgG}^{+}$cells most likely represent follicle derived $B$ cells that have reached terminal maturation locally. ${ }^{11}{ }^{12}$ IgG producing cells were found to increase strikingly with increasing degrees of inflammation in the gastric mucosa, particularly in the basal part of mucosa. ${ }^{13}{ }^{14}$

There is a disproportionate increase in IgG producing cells in inflammatory bowel disease. ${ }^{12}$ Local production of $\mathrm{IgG}_{1}$ is particularly marked in ulcerative colitis. ${ }^{15-17} \mathrm{Con}$ versely, lesions in Crohn's disease contain relatively more $\operatorname{IgG}_{2}$ cells than in ulcerative colitis. In both diseases, there is a shift from a predominance of local IgA $\mathrm{A}_{2}$ producing cells to IgA $\mathrm{A}_{1}$ producing cells, and less of the $\operatorname{Ig} \mathrm{A}$ is dimeric. In addition, epithelial expression of 
Table 1 Arbitrary scoring system for grading of severity of inflammation in rectal biopsies in shigellosis

\begin{tabular}{|c|c|c|c|c|}
\hline \multirow[b]{2}{*}{ Changes in: } & \multirow[b]{2}{*}{ Score } & \multicolumn{3}{|c|}{ Proportion of samples (\%) in } \\
\hline & & Patient 1 & Patient 2 & Control \\
\hline \multicolumn{5}{|l|}{ Mucosal surface } \\
\hline Normal & 0 & 94 & 100 & 100 \\
\hline Irregular & 1 & 6 & & \\
\hline \multicolumn{5}{|l|}{ Surface epithelium } \\
\hline Oedema & 1 & 85 & 45 & 5 \\
\hline Loss & 2 & 30 & & \\
\hline Erosion & 3 & 25 & & \\
\hline Ulceration & 4 & 4 & & \\
\hline PMN & 0 & 9 & 72 & 92 \\
\hline PMN & $1-3$ & 91 & 28 & 8 \\
\hline \multicolumn{5}{|l|}{ Crypt } \\
\hline PMN & 0 & 57 & 82 & 90 \\
\hline PMN & $1-3$ & 43 & 18 & 10 \\
\hline Abscess absent & 0 & 90 & 100 & 100 \\
\hline Abscess present & 1 & 10 & & \\
\hline \multicolumn{5}{|l|}{ Goblet cells } \\
\hline Normal number & 0 & 40 & 100 & 100 \\
\hline Lowered number & 1 & 60 & & \\
\hline Normal size & 0 & 70 & 90 & 100 \\
\hline Smaller size & 1 & 30 & 10 & \\
\hline \multicolumn{5}{|l|}{ Lamina propria } \\
\hline PMN & 0 & 13 & 67 & 88 \\
\hline $\mathrm{PMN}^{\star}$ & $1-3$ & 87 & 33 & 12 \\
\hline Oedema & 1 & 90 & 27 & 10 \\
\hline Plasma cells ${ }^{\star}$ & 0 & & 7 & 45 \\
\hline Plasma cells* & $1-3$ & 100 & 93 & 55 \\
\hline Maximum total score & 21 & & & \\
\hline
\end{tabular}

*Arbitrary frequency estimation, $0=$ no increase; $1=$ slight; $2=$ moderate; $3=$ high. Patient 1 , patient sample in the acute phase; Patient 2, patient sample at convalescence (day 30 ). PMN, polymorphonuclear cells.

secretory component is modulated in these diseases: the normally high levels of secretory component seem to be influenced by dysplastic changes, leading to reduced expression. ${ }^{18}$ On the other hand, in coeliac disease, secretory immunity is enhanced both in terms of local poly immunoglobulin production and epithelial secretory component expression. ${ }^{19}$ It has been suggested that interferon (IFN) $\gamma$ upregulates the expression of secretory component. ${ }^{12}$ In contrast, in large bowel adenoma and metaplastic polyps, the staining intensity for secretory component and epithelial IgA decreases with increasing degrees of dysplasia. ${ }^{20-22}$

The purposes of this study were to assess quantitatively the influence of shigella induced inflammation on: frequency and distribution of IgA, IgG, and IgM class and subclass expressing immunocytes in rectal mucosal biopsy specimens from patients with shigellosis; and expression of secretory component by cells in the mucosa. These parameters were analysed immunohistochemically in biopsies obtained early and late in the disease and compared with biopsies from healthy age and sex matched controls. The findings were also correlated to the degree of inflammation.

\section{Methods}

STUDY POPULATIONS

Thirty five male patients (aged 20-45 years) seen at the International Centre for Diarrhoeal Disease Research in Bangladesh with culture confirmed shigella (the only infecting organism) infection and 40 healthy subjects (control group) matched for sex, age, and socioeconomic status were included in the study. Twenty five of 35 patients were infected with $S$ dysenteriae 1 and 10 with $S$ flexneri. No other pathogenic microorganisms were found in stool culture from the patients. Neither the controls nor the patients had experienced either bloody dysentery in the six months before inclusion in the study or before the current infection. On admission, all patients exhibited clinical symptoms typical of bacillary dysentery including fever, tenesmus, and blood and mucus in their faeces. Patients were given pivmecillinam chloride $200 \mathrm{mg}$ four times daily for at least one week from the day of admission. On average, patients became culture negative and free from dysenteric symptoms within five days after initiation of pivmecillinam treatment. Patients with additional infections, or other major diseases, were not included in the study. Individuals in this study population were also included in studies relating to other aspects of the immune function in shigellosis.

\section{SAMPLES AND THEIR HISTOPATHOLOGY}

Rectal mucosal biopsies obtained at proctoscopy were obtained from each patient within 48 hours of admission (after culture confirmation) and 30-35 days thereafter. At convalescence, all patients' stool cultures were negative for infectious organisms. In controls, one set of rectal biopsies were obtained. Biopsy specimens were fixed in $10 \%$ formalin (in $50 \mathrm{mM}$ Tris buffered saline pH 7.6 (TBS) for 20 hours at room temperature) and embedded in paraffin. Sections were stained with haematoxylin and eosin for histological evaluation. To assess the degree of inflammation in the biopsy specimens, a number of morphological parameters were documented (table 1). The total score obtained by evaluating the parameters formed the basis for grading the degree of inflammation. The scoring system followed in this study was based on one used previously. ${ }^{23}{ }^{24}$

\section{IMMUNOHISTOCHEMISTRY}

Immunoperoxidase staining was performed on serial sections $(5 \mu \mathrm{m})$ of rectal mucosal biopsies. Sections were deparaffinised, rehydrated, and digested with $0.1 \%$ proteinase $\mathrm{K}$ (in TBS; Sigma Chemical, St Louis, Missouri, USA) for two to three minutes except where otherwise mentioned. Endogenous peroxidase activity was blocked by incubation in $0.3 \% \mathrm{H}_{2} \mathrm{O}_{2}$ in methanol for 30 minutes. After pre-incubation in TBS for five minutes, the slides were incubated with $20 \%$ normal rabbit serum or normal mouse serum (Dako A/S, Glostrup, Denmark) to prevent non-specific binding. The sections were then incubated ( 20 hours at room temperature) with monoclonal antibodies or rabbit antisera diluted in TBS containing $1 \%$ bovine serum albumin (BSA), followed by avidin-biotin horseradish peroxidase complex according to the instructions of the manufacturer (ABC-HRP Kit; Dako A/S). The diaminobenzidine tetra hydrochloride (diaminobenzidine; $0.5 \mathrm{~g} / 1)$ and $\mathrm{H}_{2} \mathrm{O}_{2}(0.015 \%)$ substrate reaction was developed for 10 minutes and the slides were counter stained with haematoxylin. Between the various incubation steps, the slides were washed in TBS. The following murine monoclonal antibodies were used to detect plasma cells in this study: antihuman 
Table 2 Grading of rectal biopsies from patients and controls based on the score system for severity of inflammation

\begin{tabular}{lllll}
\hline & \multicolumn{3}{c}{ Patients infected with } \\
\cline { 3 - 4 } Total score & $\begin{array}{l}\text { Inflammation } \\
\text { grading }\end{array}$ & $\begin{array}{l}\text { Sdysenteriae 1 } \\
(n=25)\end{array}$ & $\begin{array}{l}\text { S flexneri } \\
(n=10)\end{array}$ & $\begin{array}{l}\text { Controls } \\
(n=40)\end{array}$ \\
\hline Acute phase & Normal & & & $36(90 \%)$ \\
$0-2$ & Grade 1 & $9(36 \%)$ & $4(40 \%)$ & $4(10 \%)$ \\
$3-5$ & Grade 2 & $11(44 \%)$ & $4(40 \%)$ & \\
$6-8$ & Grade 3 & $5(20 \%)^{\star}$ & $2(20 \%) \dagger$ & \\
$9 \geqslant$ & Normal & $14(56 \%)$ & $8(80 \%)$ & \\
Convalescence & Grade 1 & $11(44 \%)$ & $2(20 \%)$ & \\
$0-2$ & $3-5$ & & &
\end{tabular}

mean score $13 ;$ tmean score 11

Table 3 Grading of staining intensity for secretory component (SC) in epithelial cells in rectal mucosal biopsies from patients $(n=35)$ and controls $(n=40)$

\begin{tabular}{lcll}
\hline & \multicolumn{2}{c}{ Patient sample in } & \\
\cline { 2 - 3 } SC grading & Acute phase & Convalescence & Control sample \\
\hline $0+$ & $5(14 \%)$ & & \\
$1+$ & $13(37 \%)$ & & \\
$2+$ & $5(23 \%)$ & & \\
$3+$ & $8(23 \%)$ & $10(29 \%)$ & \\
$4+$ & $1(3 \%)$ & $25(71 \%)$ & $40(100 \%)$ \\
\hline
\end{tabular}

$\operatorname{IgG}_{1} \quad$ (8c/6-39; Sigma), IgG IgP $_{2} \quad$ (HP-6014; Sigma), $\mathrm{IgG}_{3}$ (HP-6050; Sigma), IgG (HP- $_{4}$ 6025; Sigma), IgM MB-11; Sigma), IgA 1 (A118; Sigma), and IgA, (A9604D2; Southern Biotechnology, Birmingham, Alabama, USA); and B-B4 (Syndecan-1; Serotech, Oxford, UK). ${ }^{12}{ }^{15}$ For the detection of human secretory component, a rabbit antiserum against human secretory component (Dako A/S) was used which detects free or $\operatorname{IgA}$ bound secretory component. For B-B4 staining, the sections were microwaved at full power for $3 \times 5$ minute intervals in a $10 \mathrm{mM}$ citrate buffer ( $\mathrm{pH}$ 6.0) instead of undergoing protease digestion. The sections were then cooled for 20 minutes, washed in distilled water, and finally washed in TBS. They were then inserted back into the normal staining protocol.

As controls for the staining procedure, the first monoclonal antibody/antiserum was replaced by irrelevant mouse IgG or IgM, or normal rabbit immunoglobulin fraction at the same concentration as the corresponding antigen specific antibody. The biopsy specimens were analysed blindly, without prior knowledge of the diagnosis or inflammatory grading. The number of immunostained cells in the lamina propria was counted in five high power fields $(\times 400$ magnification) and the average count was expressed as the number of cells per $\mathrm{mm}^{2}$. The intensity of staining was arbitrarily graded as: 0 , no staining; $1+$, weak; $2+$, moderate; $3+$, high; $4+$, very high. The proportion of each immunoglobulin subclass was calculated in relation to the total number of immunoglobu- lin producing cells of the corresponding immunoglobulin class ( $G$ or A) present in the evaluated area of the same section. Up to five sections were examined for each subclass because of the scarcity of IgG producing cells in most specimens.

\section{STATISTICAL ANALYSES}

Comparison of data between groups and different time points were analysed using nonparametric statistical methods ( $\chi^{2}$ and MannWhitney U test), in the JMP statistical software (SAS Institute, Cary, North Carolina, USA). In each case, $\mathrm{p}<0.05$ was considered significant.

\section{Results}

HISTOPATHOLOGICAL EVALUATION

Based on an arbitrary score system the grade of inflammatory changes observed in haematoxylin and eosin stained sections was estimated. The grade of inflammation both in $S$ dysenteriae 1 and $S$ flexneri infected patients and in controls is shown in table 2 . In the acute phase, no difference in the grade of inflammation was seen between $S$ dysenteriae and $S$ flexneri. Among the 35 patients $37 \%$ had grade 1 inflammation, $43 \%$ had grade 2 , and $20 \%$ had grade 3 . In addition, $10 \%$ of the controls had grade 1 inflammation. In contrast, at convalescence, a significantly higher proportion $(\mathrm{p}<0.01)$ of the $S$ dysenteriae patients $(44 \%)$ had grade 1 inflammation compared with patients infected with $S$ flexneri $(20 \%)$.

\section{SECRETORY COMPONENT EXPRESSION}

The staining intensity for secretory component seen in the control biopsies was considered as normal and was given the arbitrary score of $4+$. Decreases in the staining intensity compared with controls were graded as $3+, 2+, 1+$ or 0 (virtually negative). A partly granular staining for secretory component was seen in the cytoplasm of crypt epithelium and in surface epithelium at the crypt orifices in the controls. In acute phase biopsies, the staining intensity for secretory component was decreased in the majority of specimens, as shown in fig 1A. The result of the secretory component staining is summarised in table 3 . In the acute phase most biopsies from $S$ dysenteriae with grade 2 inflammation had $2+$ secretory component grading while most biopsies from $S$ flexneri with grade 2 inflammation had $3+$ secretory component grading. Secretory component grading was $3+$ in $29 \%$ of the convalescence biopsies; all these samples had grade 1 inflammation and were from $S$ dysenteriae patients (fig $1 \mathrm{~B})$. The intensity of the secretory component staining was inversely correlated to the degree

Table 4 Immunocyte counts (per $\mathrm{mm}^{2}$ ) in rectal mucosal biopsy specimens from shigella infected patients and controls

\begin{tabular}{|c|c|c|c|c|c|c|c|c|}
\hline Samples & $\operatorname{Ig} A_{l}+$ cells & $I g A_{2}+$ cells & $\operatorname{Ig} G_{t}+$ cells & $\operatorname{Ig} G_{2}+$ cells & $\operatorname{Ig} G_{3}+$ cells & $\operatorname{Ig} G_{+}+$cells & $\operatorname{Ig} M^{+}$cells & Plasma cells \\
\hline Control & $360(78)(40 \%)$ & $532(118)^{\star}(60 \%)$ & $20(3)(39 \%)$ & $13(6)(25 \%)$ & 7 (3) $(14 \%)$ & $11(6)(22 \%)$ & $53(13)$ & $992(39)$ \\
\hline Patient 1 & $841(184)^{\star \star}(35 \%)$ & $1562(411) \star \star(65 \%)$ & $41(17)^{\star \star}(28 \%)$ & $55(18)^{\star \star}(38 \%)$ & $11(6)(8 \%)$ & $37(18)^{\star \star}(26 \%)$ & $69(24)$ & $2612(544)^{\star \star}$ \\
\hline Patient 2 & $674(118)^{\star}(40 \%)$ & $1017(233)^{\star}(60 \%)$ & 29 (13) (10\%) & $34(7)^{\star}(36 \%)$ & $8(5)(12 \%)$ & $19(7)(42 \%)$ & $62(17)$ & $1842(443)^{\star}$ \\
\hline
\end{tabular}

Values are mean (SD) (percentage of total IgA, IgG, IgM cells as appropriate).

Patient 1 , biopsy taken in acute phase (day 1); Patient 2, biopsy taken in convalescence (day 30 ).

${ }^{\star} \mathrm{p}<0.05$ compared with control; ${ }^{\star \star} \mathrm{p}<0.05$ compared with patient 2 . 

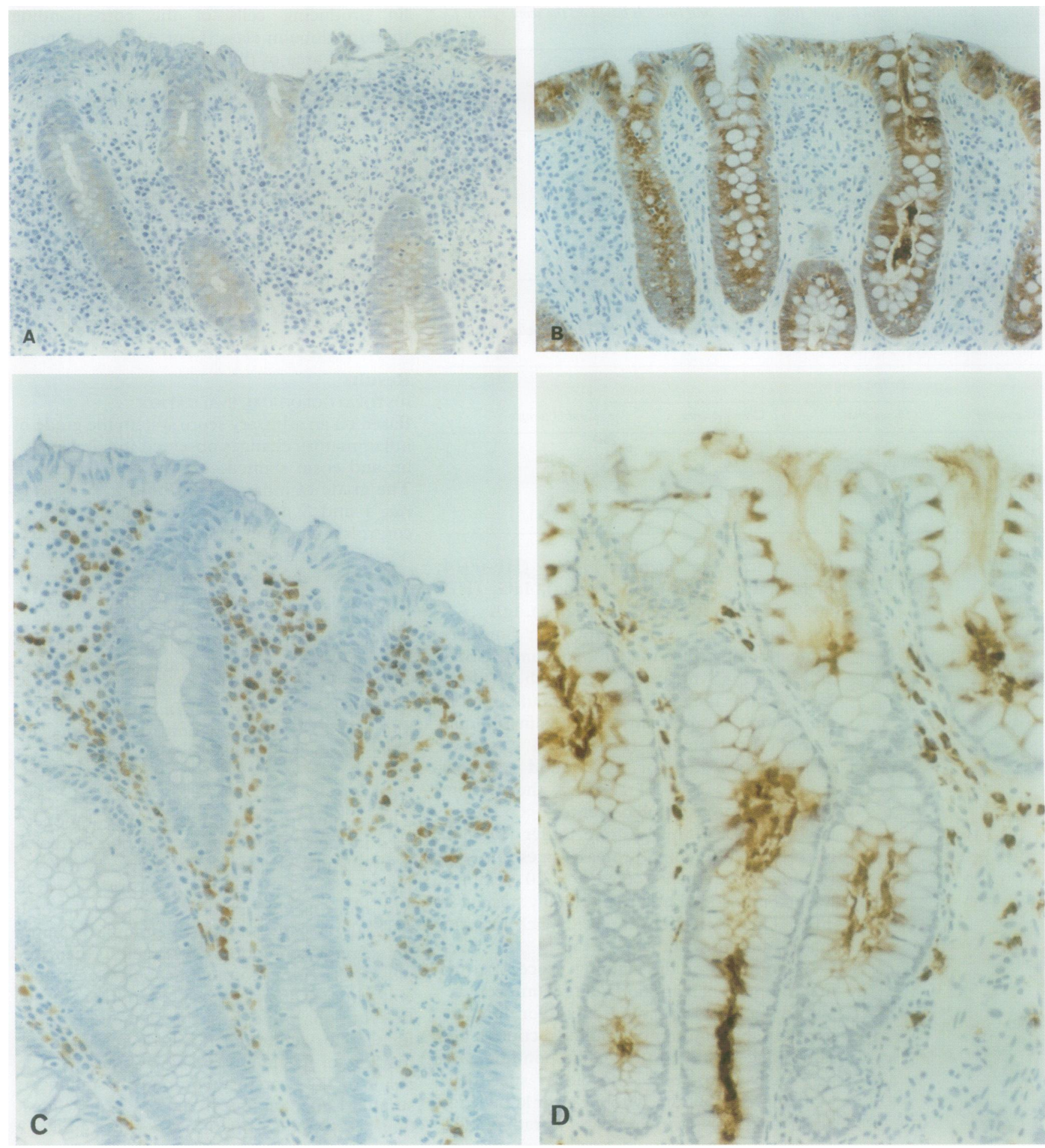

Figure 1 Immunohistochemical staining of paraffin sections of rectal mucosal biopsies taken in the acute phase of shigellosis and at convalescence. All sections were counter stained with haematoxylin. $(A)$ Staining with the antihuman secretory component antiserum in acute phase biopsies shows very light staining of crypt epithelial and surface epithelial cells compared with (B) convalescent biopsies, where an intense brown staining is seen in both cell types and in the crypt lumen. (C) Staining of IgA, positive cells in the acute phase shows a high proportion of positive cells in the lamina propria but negative staining in crypt epithelial and surface epithelial cells, whereas in convalescent biopsies (D), it shows fever IgA, positive cells in the lamina propria and positive staining in crypt epithelial cells, surface epithelial cells, and the crypt lumen. Original magnification $\times 125$.

of inflammation in control and patient biopsies (not shown).

SUBCLASS DISTRIBUTION OF IMMUNOGLOBULIN PRODUCING CELLS IN RECTAL BIOPSIES FROM PATIENTS AND CONTROLS

IgA positive plasma cells were most numerous in the upper two thirds of the lamina propria (fig 1C-F). In the acute phase biopsies, the frequency of $\operatorname{IgA}_{1}$ (mean (SD) 841 (184)) and IgA $_{2}(1562$ (311)) staining cells was significantly higher than at convalescence and in control biopsies (table 4). In biopsies from convalescent patients, the number of both $\operatorname{Ig} \mathrm{A}_{1}$ and $\operatorname{IgA} \mathrm{A}_{2}$ positive cells was significantly higher $(p<0.01)$ than in controls. In the acute phase, $65 \%$ of the $\operatorname{IgA}$ positive cells were $\operatorname{Ig} \mathrm{A}_{2}$ positive compared with $60 \%$ both in control and convalescence biopsies (table 4). In the acute phase, the number of $\operatorname{Ig} \mathrm{A}_{2}$ positive cells showed a positive correlation with the degree of inflammation, irrespective of whether the patients were infected with $S$ dysenteriae or $S$ flexneri (not shown). The intra-epithelial stain- 


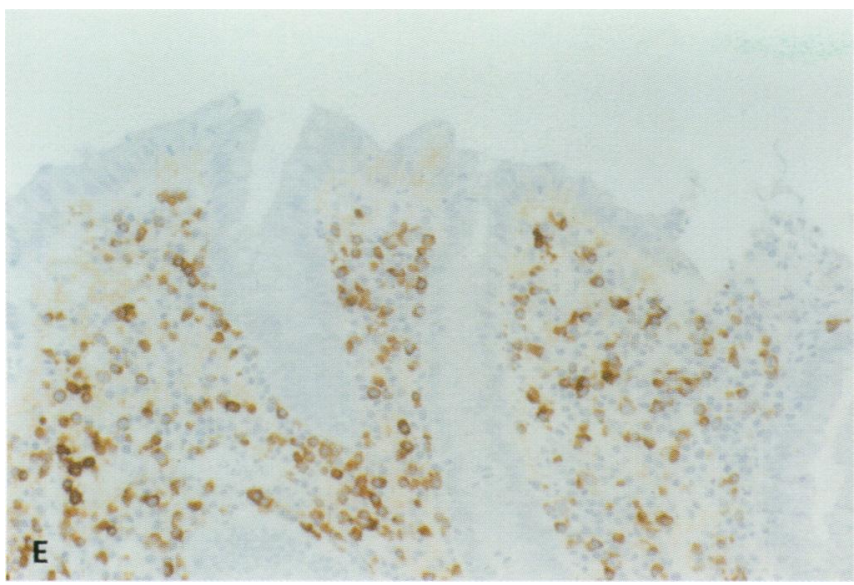

Figure 1 (continued) Immunohistochemical staining of paraffin sections of rectal mucosal biopsies taken in the acute phase of shigellosis and at convalescence. All sections were counterstained with haematoxylin. (E) Staining of Ig $A_{2}$ positive cells in acute phase biopsies shows a higher proportion of $\operatorname{Ig} A_{2}$ positive cells than $\operatorname{Ig} A_{1}$ positive cells in the lamina propria. (F) At convalescence, there is a decreased number of $\operatorname{Ig} A$, positive cells in the lamina propria but positive staining is seen in crypt epithelial cells and in the crypt lumen. Original magnification $\times 125$.

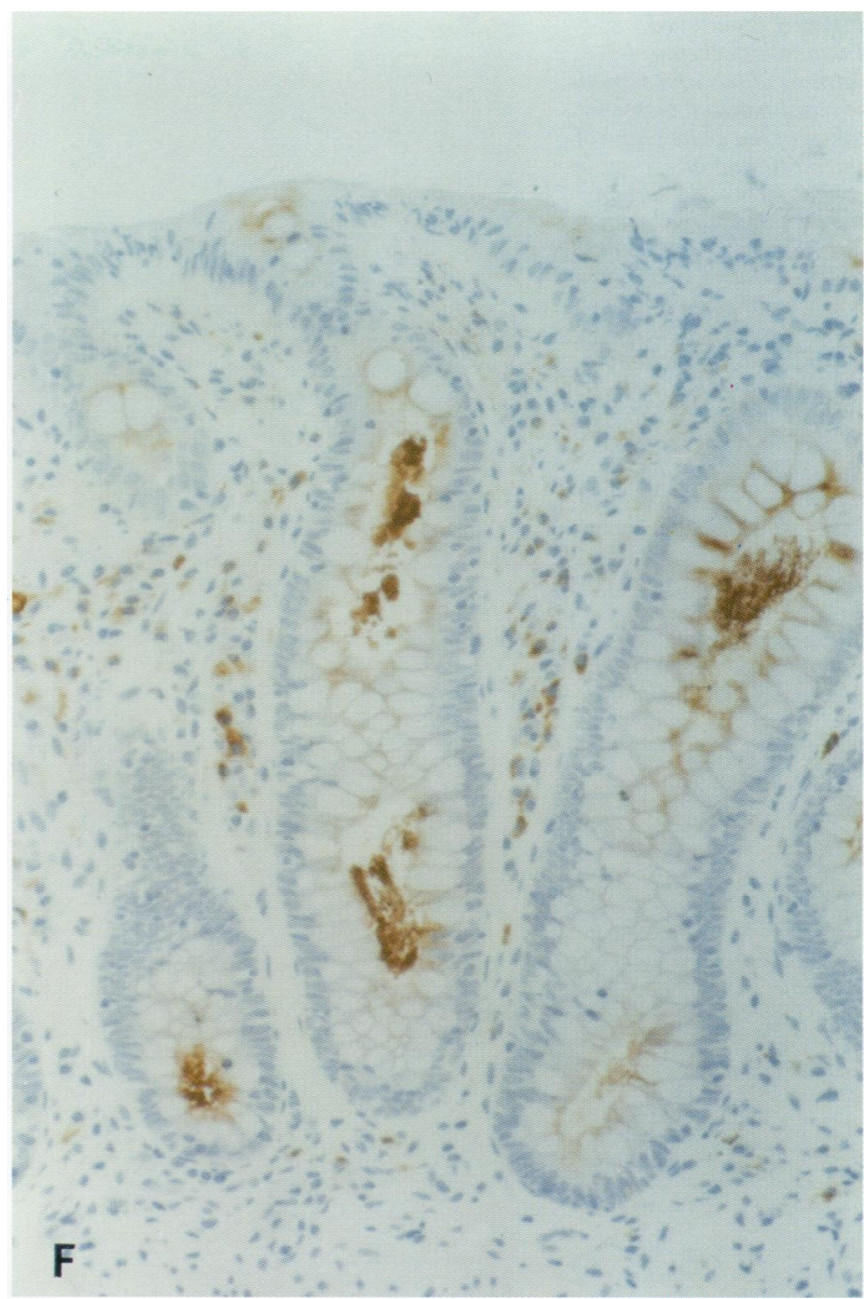

the number of B-B4 positive plasma cells was significantly higher $(1842$ (443), $\mathrm{p}<0.01)$ than in the controls. In the acute phase biopsies, most plasma cells were found just beneath the surface epithelim. However, at convalescence, the B-B4 stained cells were mostly located in the middle part of the lamina propria. Summation of the IgA, IgG, and IgM positive plasma cells deviated not more than $5 \%$ from the number of B-B4 positive plasma cells.

similar to that of acute phase, whereas in controls it was $\operatorname{IgG}_{1}>\mathrm{IgG}_{2}>\mathrm{IgG}_{4}>\mathrm{IgG}_{3}$. At convalescence, only $\mathrm{IgG}_{2}$ producing cells were significantly higher than in the controls. The $\mathrm{IgG}_{4}$ positive cells were more predominant in the lower part of the lamina propria (figs 1G and $\mathrm{H}$ ). In contrast, $\mathrm{IgG}_{1}, \mathrm{IgG}_{2}$, and $\mathrm{IgG}_{3}$ positive cells were more evenly distributed throughout the lamina propria.

The number of IgM positive cells in acute phase biopsies was not significantly different from that in controls (table 4).

\section{DISRIBUTION OF PLASMA CELLS}

As an additional plasma cell marker, biopsy specimens were stained for Syndecan-1 using the monoclonal antibody B-B4. This antibody also stained surface and crypt epithelial cells. In acute phase biopsies, a significantly higher number (mean (SD) 2612 (544), p < 0.001) of B-B4 positive plasma cells (fig 1I) was seen than in biopsies from controls or convalescent patients. Also, in convalescence biopsies (fig 1J)

\section{Discussion}

We have characterised local inflammatory and immunological changes following shigella infection in adult patients. The frequency of immunoglobulin producing cells was positively correlated to the degree of inflammation. Using a detailed scoring system for inflammation, we found that a persistent mucosal inflammation was more frequent in $S$ dysenteriae 1 infection (44\%) than in $S$ flexneri infection (20\%). Previously, histopathological findings in the rectal mucosa in shigellosis has been studied mostly in the acute phase. ${ }^{7826-29}$ In this study, we confirmed and extended the observations of a persistent inflammation and have shown that this is more frequent in $S d y s$ enteriae than in $S$ flexneri infection. The local gut humoral immune responses in shigellosis result preferentially in $\operatorname{IgA}$ (both $\operatorname{Ig} \mathrm{A}_{1}$ and $\operatorname{Ig} \mathrm{A}_{2}$ ) and $\mathrm{IgG}_{2}$ cell expansion. The IgA producing cell expansion also reflects the mucosal lesion 
Figure 1 (continued) Immunohistochemical staining of paraffin sections of rectal mucosal biopsies taken in the acute phase of shigellosis and at convalescence. All sections were counterstained with haematoxylin. (G) Staining of $I g G_{4}$ positive cells in acute phase biopsies shows a higher proportion of $\mathrm{IgG}_{4}$ positive cells in the lamina propria than $(H)$ at convalescence. (I) Staining of plasma cells with the anti-B-B4 monoclonal antibody (Syndecan-1) in acute phase biopsies shows an increased number of $B-B 4$ positive cells compared with (7) convalescent biopsies. Original magnification: $\times 94$ ( $G$ and $H$ ), and $\times 187$ ( $I$ and $¥$ ).
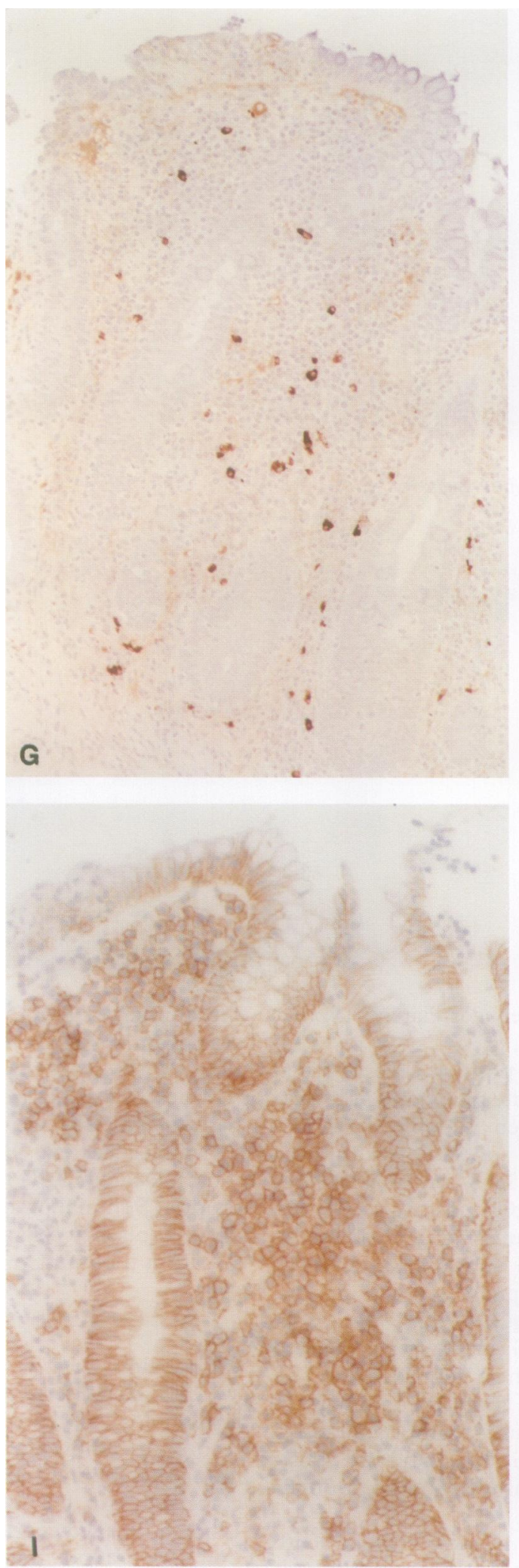

more accurately than IgG producing cell expansion in shigellosis.

In shigellosis it is reasonable to assume that the majority of shigella specific antibodies is derived from immunoglobulin producing cells in the infected colonic mucosa. In this study, a higher $\operatorname{Ig} \mathrm{A}_{2}: \operatorname{Ig} \mathrm{A}_{1}$ plasma cell ratio was seen in acute phase biopsies than in controls, although both $\operatorname{Ig} \mathrm{A}_{1}$ and $\operatorname{Ig} \mathrm{A}_{2}$ producing cells increased significantly in the acute phase biopsies. Previous work has shown that biopsies of patients with acute infectious colitis have a larger
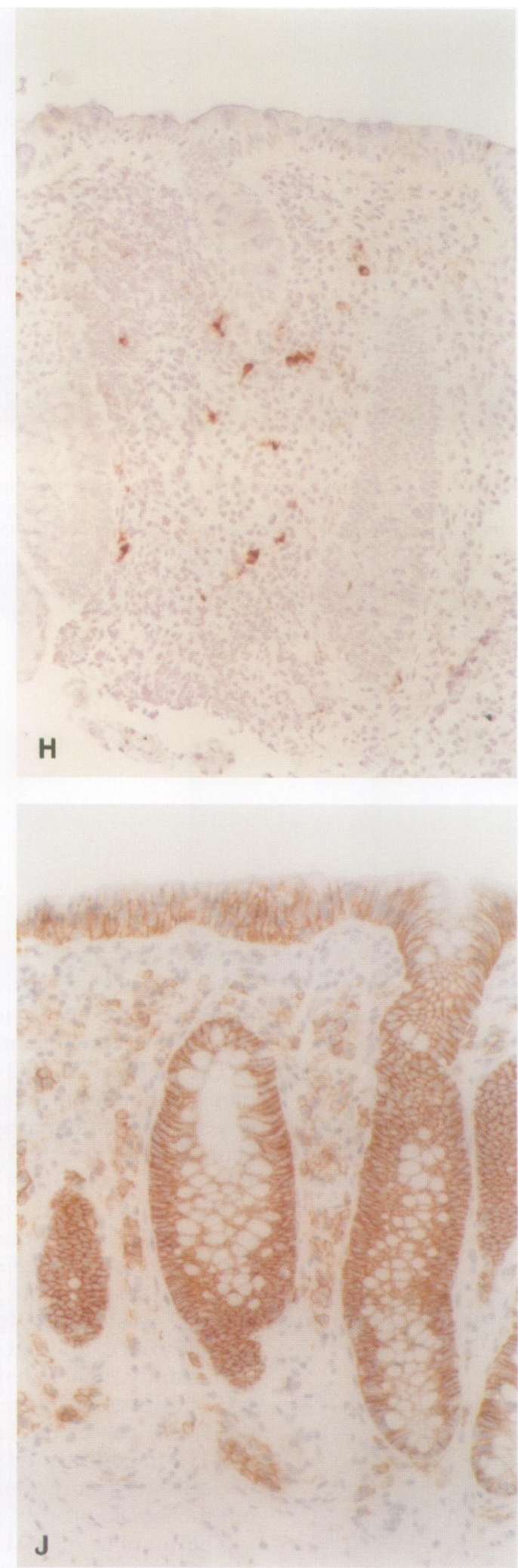

increase in the numbers of IgA producing cells than of cells producing other immunoglobulin classes. ${ }^{30}$ In addition, we have previously shown an increase in faecal sIgA and serum $\operatorname{IgA} \mathrm{A}_{2}$ antibodies specific for shigella antigens in shigellosis, ${ }^{31}$ and others have shown that $\operatorname{sigA}$ antibodies to lipopolysaccharide are mainly of the IgA subclass. $^{32}$ In this study, the serum level of $\operatorname{Ig} \mathrm{A}_{2}$ was also significantly increased in patients compared to controls. ${ }^{31}$ We have also shown increased serum level of $\operatorname{Ig} A_{1}$ antibodies specific for shigella antigens in previous studies 
of shigellosis. ${ }^{31}$ This may suggest that there is an early massive increase in mucosal $\mathrm{IgA} \mathrm{A}_{2}$ production in response to the shigella infection, at least some of which is shigella antigen specific and may appear in the serum.

We observed a decrease in secretory component and IgA staining in crypt and surface epithelium in the acute phase, correlating with the degree of inflammation, in spite of an increased number of IgA subclass positive cells. Previously, we have also shown that total IgA (tIgA) as well as sIgA is greatly increased in the stools of patients with acute shigellosis. ${ }^{31}$ This was most prominent in patients with severe disease. ${ }^{33}$ Thus, in these patients there is an increased local production of $\operatorname{IgA}$ in the inflamed mucosa that is transported into the gut lumen both by secretory component dependent and non-dependent mechanisms. Previously we have shown the loss of serum proteins (IgG, albumin, and IgA) into the faeces, probably due to ulceration or exudation through the inflamed mucosal epithelium. The lack of secretory component and IgA staining in gut epithelium in these patients could be due also to a more rapid transepithelial transport, giving less of an intra-epithelial accumulation of secretory component and IgA. The effect of modulation by proinflammatory cytokines on the turnover of secretory component has already been reported. ${ }^{94}$ Recently, analysis of the production of cytokines in the gut mucosa in acute and convalescent phase of shigellosis has revealed a complex pattern of proinflammatory and $\mathrm{T}$ helper $1 \quad\left(\mathrm{Th}_{1}\right)$ and $\mathrm{Th}_{2}$ associated cytokines. ${ }^{35-38}$ However, mucosal levels of IFN $\gamma$ and IFN $\gamma$ receptors were lower in the acute phase compared with the convalescent phase of the disease. ${ }^{36-38}$ It is not clear whether this decrease in IFN $\gamma$ may influence the level of expression of secretory component in shigellosis. In coeliac disease it has been suggested that IFN $\gamma$ upregulates the expression of secretory component. ${ }^{12}$ At convalescence, the still increased frequency of IgA positive cells was associated with a gut epithelium that had regained secretory component and IgA stainability. At the same time, faecal tIgA and $\operatorname{sIgA}$ had returned to control levels. ${ }^{31}$ Again, this may suggest that faecal IgA levels are regulated by the rate of transepithelial IgA transport.

We also found an increased number of IgG positive cells in the rectal mucosa as well as alterations in their IgG subclass distribution during shigellosis. A higher number of $\mathrm{IgG}_{2}$ positive cells was seen in the rectal mucosa of acute phase patients than in the controls. This correlates with our previous findings of an early increase in $\operatorname{IgG}_{2}$ serum antibodies specific for shigella lipopolysaccharide. ${ }^{31}$ This correlation may suggest that the majority of the shigella specific serum IgG $_{2}$ antibodies are derived from the rectal mucosa. In vitro experimental data and in vivo studies indicate a role for specific factors in inducing or enhancing the production of immunoglobulin molecules of particular subclasses. The interleukin (IL)-4 and IL-13 produced by $\mathrm{Th}_{2}$ and $\mathrm{Th}_{0}$ cells, respectively, are associated with the enhance- ment of $\mathrm{IgG}_{1}$ and $\mathrm{IgG}_{4}$ production, ${ }^{39}{ }^{40}$ whereas IFN $\gamma$ produced by $T_{1}$ and natural killer cells has been suggested to induce the production of $\mathrm{IgG}_{2}$ and $\mathrm{IgG}_{3} \cdot{ }^{41-43}$ However, a complex pattern of proinflammatory and $\mathrm{Th}_{1}$ and $\mathrm{Th}_{2}$ associated cytokines ${ }^{35-38}$ would be necessary for the observed IgG and IgA subclass pattern in this study. Our findings of a preferential increase of $\operatorname{IgA}_{2}$ and $\operatorname{IgG}_{2}$ positive cells in rectal mucosa in the acute phase of disease is reminiscent of findings in coeliac disease, a disease characterised by an increase of intra-epithelial lymphocytes. ${ }^{16}$ Interestingly, in shigellosis an increase in intra-epithelial lymphocytes can be found also (unpublished observation).

Our findings thus indicates that: there is an induction of the gut mucosal humoral immune response in shigellosis, which persists long after the clinical resolution of the disease; at least a proportion of shigella specific IgA and IgG serum antibodies may be derived from the local mucosal immune response; there is a preference for $\operatorname{IgA}_{2}$ and $\operatorname{IgG}_{2}$ production; the secretory component mediated transepithelial IgA transport is enhanced in shigellosis; and the local inflammatory response in shigellosis, particularly in $S$ dysenteriae 1 infection, is prolonged.

Further studies are needed to evaluate the shigella antigen specificity of the locally immunoglobulin producing cells and the beneficial or detrimental consequences of the marked local IgA responses in shigellosis.

We are indebted to the individuals with shigellosis and healthy individuals from Bangladesh for their participation in the study. We also acknowledge the staff of the study ward of the Clinical Research Centre of the International Centre for Diarrhoeal Disease Research, Bangladesh (ICDDR,B). We thank Anita Lindström, Inger Buskas, and Birgitta Axelsson (Divisions of Pathology, Karolinska Institute, Huddinge University Hospital, Huddinge, Sweden) for technical assistance. This study was Huddinge, Sweden) for technical assistance. This study was supported by a grant from the Swedish Agency for Research the Swedish Medical Research Council (Grant no. 16x 656), the Swedish Medical Research Council
and funds of the Karolinska Institute.

1 Speelman P, Mc-Glaughlin R, Kabir I, Butler T. Differential clinical features and stool findings in shigellosis and amoebic dysentery. Am $\mathcal{F}$ Trop Med Hyg 1987;81:549-51.

2 Sansonetti PJ, Ryter A, Clerc P, Maurelli AT, Mounier J. Multiplication of Shigella flexneri within HeLa cells: lysis of the phagocytic vacuole and plasmid-mediated contact hemolysis. Infect Immun 1986;51:461-9.

3 Menard R, Sansonetti PJ, Parsot C. Nonpolar mutagenesis of the ipa genes defines IpaB, IpaC, and IpaD as effectors of Shigella flexneri entry into epithelial cells. $\mathcal{F}$ Bacteriol 1993;175:5899-906.

4 Gigh N, Mounier J, Prevost MC, Sansonetti PJ. IpaB of Shigella flexneri causes entry into epithelial cells and escape from the phagocytic vacuole. EMBO ₹ 1992;11 $1991-9$.

5 Speelman P, Kabir I, Islam M. Distribution and spread of colonic lesions in shigellosis: a colonoscopic study. $\mathcal{f}$ Infect Dis 1984;150:899-903.

6 Mathan MM, Mathan VI. Morphology of rectal mucosa of patients with shigellosis. Rev Infect Dis 1991;13(Suppl 4):S314-18

7 Streulens MJ, Patte D, Kabir I, Salam A, Nath SK, Butler T. Shigella septicemia: prevalence, presentation, risk factor and outcome. F Infect Dis 1985;152:784-90.

8 Islam MM, Azad AK, Bardhan PK, Raqib R, Islam D. Pathology of shigellosis and its complications. Histopathol ogy 1994;24:65-71.

9 Brandtzaeg P, Halstensen TS, Kett K, Krajci P, Kvale D, Rognum TO, et al. Immunobiology and immunopathology of human gut mucosa: humoral immunity and intrae

10 Matsueda K, Yamada G, Tsuji T. Immunohistochemical characterization of the lymphocyte and the immunoglobulin-containing cell in the epithelium and the lamina propria of normal human intestines. Acta Med Okayama 1991;45:161-9.

11 Bjerke K, Brandtzaeg P, Rognum TO. Distribution of immunoglobulin producing cells is different in normal human appendix and colon. Gut 1986;27:667-74 
12 Brandtzaeg $\mathrm{P}$, Bjerke $\mathrm{K}$, Kett $\mathrm{K}$, Kvale D, Rognum TO, Scott $\mathrm{H}$, et al. Production and secretion of immunoglobulins in the gastrointestinal tract. Ann Allergy 1987;59:21 39

13 Valnes K, Brandtzaeg P, Elgio K, Stave, R. Quantitative distribution of immunoglobulin-producing cells in gastric mucosa: relation to chronic gastritis and glandular atrophy. Gut 1986;27:505-9.

14 Valnes K, Brandtzaeg P. Subclass distribution of mucosal IgG-producing cells in gastritis. Gut 1989;30:322-6.

15 Brandtzaeg P, Kett K, Rognum TO. Subclass distribution of IgG- and IgA-producing cells in secretory tissues and alterations related to gut diseases. Adv Exp Med Biol 1987; 216A: $321-33$

16 Brandtzaeg P, Kett K, Halstensen TS, Helgeland L. Pathogenesis of ulcerative colitis and Crohn's disease: humora immune mechanisms. Eur $\mathcal{F}$ Gastrointerol Hepatol 1990;2 256-65

17 Scott MG, Nahm MH, Macke K, Nash GS, Bertovich MJ, MacDermott RP. Spontaneous secretion of IgG subclasses by intestinal mononuclear cells: differences between ulcerative colitis, Crohn's disease, and controls. Clin Exp Immunol 1986;66:209-15.

18 Brandtzaeg P, Halstensen TS, Huitfeldt HS, Krajci P, Kvale D, Scott H, et al. Epithelial expression of HLA, secretory component (poly-Ig receptor), and adhesion molecules in the human alimentary tract. Ann N Y Acad Sci 1992;664 the human

19 Kett K, Scott H, Fausa O, Brandtzaeg P. Secretory immunity in celiac disease: cellular expression of immunoglobulin A subclass and joining chain. Gastroenterology 1990;99:386-92.

20 Rognum TO, Fausa O, Brandtzaeg P. Immunohistochemical evaluation of carcinoembryonic antigen, secretory component, and epithelial IgA in tubular and villous largebowel adenomas with different grades of dysplasia. Scand f Gastroenterol 1982;17:341-8.

21 Rognum TO, Elgio K, Fausa O, Brandtzaeg P. Immunohistochemical evaluation of carcinoembryonic antigen, secretory component, and epichelial IgA in ulcerative colitis with dysplasia. Gut 1982;23:123-33.

22 Jass JR, Faludy J. Immunohistochemical demonstration of IgA and secretory component in relation to epithelial cell differentiation in normal colorectal mucosa and metaplasdifferentiation in normal colorectal mucosa and metaplastic polyp:

23 Reinholt FP, Veress B, Lindquist K, Liljeqvist L. Qualitative assessment and morphometry in the study of the ileal reservoir after restorative proctocolectomy. APMIS 1989;97: 97-104.

24 Veress B, Reinholt FP, Lindquist K, Liljeqvist L. Different types of mucosal adaptation in the ileal reservoir after restorative proctocolectomy. A two-year follow-up study. APMIS 1990;98:786-96.

25 Pellat-Deceunynck C, Bataille R, Robillard N, Harousseau JL, Rapp MJ, Juge-Morineau N, et al. Expression of CD28 and CD40 in human myeloma cells: a comparative study and CD40 in human myeloma cells: a comparative

26 Mathan MM, Mathan VI. Ultrastructural pathology of the rectal mucosa in Shigella dysentery. Am f Pathol 1986;123: $25-38$.
27 Mathew M, Mathan MM, Mani K, George R, Jebakumar K, Dharamsi $\mathrm{R}$, et al. The relationship of microbial pathogen to acute infectious diarrhoea of childhood. 7 Trop Med Hyg 1991;94:253-60.

28 Butler T, Dunn D, Dahms B, Islam M. Causes of death and the histopathologic findings in fatal shigellosis. Pediatr Infect Dis F 1989;8:767-72.

29 Sachdev HP, Chadha V, Malhotra V, Verghese A, Puri RK. Rectal histopathology in endemic shigella and salmonella diarrhea. 7 Pediatr Gastroenterol Nutr 1993;16:33-8.

30 Spreeuwel JPV, Lindeman J, Meijer CJLM. A qualitative study of immunoglobulin containing cells in the differential diagnosis of acute colitis. $\mathcal{F}$ Clin Pathol 1985;38:774-7.

31 Islam D, Wretlind B, Ryd M, Lindberg AA, Christensson B. Immunoglobulin subclass distribution and dynamics of Shigella-specific antibody responses in serum and stoo samples in shigellosis. Infect Immun 1995;63:2054-61.

32 Mestecky J, Russell MW. IgA subclasses. Monogr Allerg 1986;19:277-80

33 Islam D, Wretlind B, Hammarström L, Christensson B, Lindberg AA. Semi-quantitative estimation of shigella antigen specific IgG, IgA and IgM antibodies: correlation to disease severity during shigellosis. APMIS 1996;104:563 74.

34 Sartore RB. Viewpoints on digestive disease. Gastroenterology 1994;106:533-9.

35 Raqib R, Lindberg AA, Wretlind B, Bardhan PK, Andersson U, Andersson J. Persistence of local cytokine production in shigellosis in acute and convalescent stages. Infect Immun 1995;63:289-96.

36 Raqib R, Ljungdahl A, Lindberg AA, Andersson U, Andersson J. Local entrapment of interferon $\gamma$ in the recovery from Shigella dysenteriae type 1 infection. Gut 1996;38:328-36.

37 Raqib R, Lindberg AA, Björk L, Bardhan PK, Andersson U Andersson J. Down-regulation of gamma interferon, tumo necrosis factor type I, interleukin 1 (IL-1) type I, IL-3, IL-4, and transforming growth factor $\beta$ type I receptors at the local site during the acute phase of shigella infection. Infect Immun 1995;63:3079-87.

38 Raqib R, Wretlind B, Andersson J, Lindberg AA. Cytokin secretion in acute shigellosis is correlated to disease activity and directed more to stool than to plasma. 7 Infect Dis 1995;171:376-84.

39 Punnonen J Aver. G Cocks BG McKenzie ANJ, Menon $S$, Zurawski G, et al. Interleukin 13 induces interleukin independent $\mathrm{IgG}_{4}$ and IgE synthesis and $\mathrm{CD} 23$ expression by human B cells. Proc Natl Acad Sci USA 1993;90:3730

40 Paul WE. Interleukin-4: prototypic immunoregulatory lymphokine. Blood 1991;77:1859-70.

41 Snapper CM, Paul WE. Interferon $\gamma$ and B cell stimulatory factor-1 reciprocally regulate $\mathrm{Ig}$ isotype production. Science 1987;236:944-7.

42 Snapper CM, McIntyre TM, Mandler R, Pecanha LMT, Finkelman FD, Lees $\mathrm{A}$, et al. Induction of $\mathrm{IgG}_{3}$ by interferon $\gamma$ : a model for $\mathrm{T}$ cell-independent class switching in response to $\mathrm{T}$ cell-independent type 2 antigen. $\mathcal{F}$ Exp Med 1992;175:1367-71.

43 Amigorena S, Bonnerot C, Fridman WH, Teillaud JL. Recombinant interleukin 2-activated natural killer cells regulate IgG2a production. Eur F Immunol 1990;20:1781-7. 